Article

\title{
Linking the Physicochemical Properties of Calcined Titania Nanoparticles with Their Biocidal Activity
}

\author{
Changseok Han ${ }^{1, *}$, Miguel Pelaez ${ }^{1}$, Doris Betancourt ${ }^{2}$, Hyeok Choi ${ }^{3}$, \\ Dionysios D. Dionysiou ${ }^{1, *}$ and Bellina Veronesi ${ }^{4}$ \\ 1 Department of Biomedical, Chemical and Environmental Engineering, University of Cincinnati, Cincinnati, \\ OH 45221-0012, USA; miguel.pelaez@kemira.com \\ 2 National Risk Management Research Laboratory, U.S. Environmental Protection Agency, \\ Research Triangle Park, NC 27711, USA; betancourt.doris@epa.gov \\ 3 Department of Civil Engineering, The University of Texas at Arlington, Arlington, TX 76019-0308, USA; \\ hchoi@uta.edu \\ 4 National Health and Environmental Effects Research Laboratory, U.S. Environmental Protection Agency, \\ Research Triangle Park, NC 27711, USA; bellinav@gmail.com \\ * Correspondence: changseok.han94@gmail.com (C.H.); dionysios.d.dionysiou@uc.edu (D.D.D.); \\ Tel.: +1-513-556-0724 (D.D.D.); Fax: +1-513-556-4162 (D.D.D.)
}

Academic Editor: Mady Elbahri

Received: 27 October 2016; Accepted: 13 December 2016; Published: 20 December 2016

\begin{abstract}
Titanium dioxide nanoparticles $\left(\mathrm{nTiO}_{2}\right)$ show biocidal activity when exposed to UV illumination. Modification of their physical properties can expand their photoresponse region toward visible light. In this study, such modification was made through a sol-gel synthesis followed by calcination at a range of temperatures $\left(250-900{ }^{\circ} \mathrm{C}\right)$, generating a series of $\mathrm{nTiO}_{2}$ particles with different crystal phases, sizes, porosities, zeta potentials, and BET surface areas. The unique properties of $\mathrm{nTiO}_{2}$ were linked to their toxicity to the marine bacterium, Vibrio fischeri. A modified "Flash" high-through put assay was used to test the viability of these marine organisms after short term (15-60 min) exposure under visible light only to the individual groups of $\mathrm{nTiO}_{2}(500-2000 \mu \mathrm{g} / \mathrm{mL})$. Linear regression analysis indicated that across all concentrations and time points, high biocidal activity correlated with the amorphous and anatase crystal phases, high BET surface area, high pore volume and small crystal size. The linkage between physicochemistry and nanotoxicity would be helpful for future design of more efficient and sustainable $\mathrm{nTiO}_{2}$.
\end{abstract}

Keywords: nanotoxicity; sustainability; $\mathrm{TiO}_{2}$ nanoparticles; titania; physicochemical; ecotoxicity; Vibrio fischeri; "Flash" assay

\section{Introduction}

Nanosize titanium dioxide particles $\left(\mathrm{nTiO}_{2}\right)$ are used in environmental remediation (water purification), consumer supplies (paints, cosmetics, sunscreens) and medical devices [1-8]. The biocidal properties of $\mathrm{nTiO}_{2}$ are based on its photoactivation by UV radiation ( $<380 \mathrm{~nm}$ for anatase and $<400 \mathrm{~nm}$ for rutile) which generates a variety of reactive oxygen species (ROS) (e.g., superoxide anion, hydroxyl radical, and singlet oxygen) [9,10]. ROS is effective against Gram-positive and Gram-negative bacteria, filamentous and unicellular fungi, algae, protozoa and viruses [3,7,10-12] and toxicity studies on $\mathrm{nTiO}_{2}$ have been conducted in various species [13-22].

Applications using conventional $\mathrm{nTiO}_{2}$ are restricted by its photosensitivity to UV wavelengths. Various methods (e.g., doping, surface coating, calcination) are used to decrease the band-gap energy of $\mathrm{nTiO}_{2}$ which increases its photosensitivity to visible/near visible radiation wavelengths [23-27]. Although these procedures often create more sustainable and effective materials, their toxic threat to the environment and "at-risk" species must be addressed. 
Recent studies link the physicochemical properties (e.g., crystal size, Brunauer, Emmett and Teller (BET) surface area, and pore volume) of commercial $\mathrm{nTiO}_{2}$ to its toxicity. To better understand how subtle changes in these properties modify biocidal activity, a series of lab-synthesized $\mathrm{nTiO}_{2}$ particles with different properties, calcined at different temperatures, was tested for their relative toxicity to the marine bacteria, Vibrio fischeri, a Gram negative, bioluminescent micro-organism [28]. The Vibrio fischeri transforms a fraction of its metabolic energy into bioluminescence. The organisms' auto-lumination reflects their viability, which can be measured spectrophotometrically in the absence of any reagents. Because of this, the Vibrio Fischeri micro-organisms has been used to assess the potential toxicity of ecotoxic substances [29-34]. In this study, a high-through-put (HTP) "Flash" assay (EN ISO 11348-1) was used to measure the toxicity of the modified $\mathrm{nTiO}_{2}$ to Vibrio Fischeri micro-organism. This commercially available assay has been used to test the micro-biocidal effects of a variety of environmental and industrial samples [29,35-37], including nanoparticles [30-32,38,39]. Use of the Vibrio fischeri in this assay is especially valuable in view of the need to examine the potential toxicity of the increasing number of materials entering aquatic marine environments $[14,19,40]$.

The in vitro screening of particles and chemicals, using commercially available, rapid and cost-effective cell assays, provides valuable "first-tier" level data on their potential toxicity. This study uses such a "screen" and the luminating marine bacteria Vibrio fischeri to demonstrate that modified $\mathrm{nTiO}_{2}$ particles are biocidal in the absence of UV illumination and that their relative toxicity can be associated with several physicochemical characteristics. Such data are essential to the design of safer, effective and more sustainable nanomaterials in environmental remediation.

\section{Experimental Section}

\subsection{Synthesis and Physicochemical Characterization}

The procedures to synthesize and characterize the $\mathrm{nTiO}_{2}$ in this study have been published previously [41]. Briefly, titanium tetraisopropoxide (TTIP, Sigma-Aldrich, St. Louis, MI, USA) as a $\mathrm{TiO}_{2}$ molecular precursor was added to isopropanol ( $i-\mathrm{PrOH}$, Fisher Inc, Waltham, MA, USA) and water. The molar ratio of the $\mathrm{H}_{2} \mathrm{O} / i-\mathrm{PrOH} / \mathrm{TTIP}$ sol was 100/30/1. After hydrolysis and condensation reactions under vigorous stirring, $\mathrm{TiO}_{2}$ particles were formed. They were recovered by filtration and purified by refluxing with acetonitrile (Fisher Inc) several times. Finally, they were dried at room temperature for $24 \mathrm{~h}$. The resulting "as synthesized" (as-syn) nTiO 2 particles were calcined at temperatures of $250-900{ }^{\circ} \mathrm{C}$ in a furnace (Paragon HT-22-D) to transform them to crystal phase $\mathrm{TiO}_{2}$ particles.

The crystal size of $\mathrm{TiO}_{2}$ was determined by using the Scherrer equation from the XRD peak broadening analysis at (101) obtained using a Kristalloflex D500 diffractometer (Siemens, Munich, Germany) with $\mathrm{Cu} \mathrm{K} \alpha(\lambda=1.5406 \AA)$ radiation. Its BET surface area and pore volume were measured based on nitrogen adsorption and desorption isotherms using Tristar 3000 analyzer (Micromeritics, Norcross, GA, USA). The zeta potential of $\mathrm{nTiO}_{2}$ was immediately measured using a ZetaSizer nano ZS (Malvern Inc., Southborough, MA, USA) in 10-20 $\mu \mathrm{g} / \mathrm{mL}$ suspensions of photobacterium marine broth (Carolina Biological Supply, Burlington, NC, USA) after ultra-sonication (see below). The data (4 measures) were collected and calculated into zeta potentials using the Smoluchowski equation [42,43]. Averages of zeta potentials were analyzed using a one-way ANOVA followed by a Tukey's post-analysis and graphed using Graph Pad Prism 5. An attempt was made to measure particle size distribution using dynamic light scattering (DLS). This technique measures the diffusion of particles moving under Brownian motion, and converts this to size and size distribution using the Stokes-Einstein relationship. However, a stable solution of suspended particles is necessary for valid measurement of Z-averages (d. nm), (i.e., the average diameter of the particles). Because of the high osmolarity of the marine broth, the individual samples were settled out of suspension within a few minutes (below the instruments minimal time for the initial cuvette readings), preventing DLS particle size measurements. 


\subsection{Storage and Light Exposure of Modified $n T i \mathrm{O}_{2}$ Samples}

After the calcination process, synthesized $\mathrm{nTiO}_{2}$ samples were stored in the dark upon receipt until used. In preparation for the plate exposures, stock suspensions of each sample were ultra-sonicated using a Daiger Ultrasonic processor (Model GE 750 watt, Sonics ${ }^{\circledR}$, Newtown, CT, USA) at a reduced amplitude of $20 \%$ for 5-7 min under dim fluorescence lighting. Stock concentrations (10-fold) were prepared and exposed under low fluorescent lighting to the 96 well plates containing the population-he adjusted bacteria plate (see below). The 96 well microplate, containing bacteria exposed to the various samples of modified $\mathrm{nTiO}_{2}$ was automatically transferred into the luminometer and the chamber door closed from all visible light. The microplate remained in the dark for the remainder of the 60 min exposure.

\subsection{Microorganisms and Viability Assay}

Vibrio fischeri (ATCC 49387) were grown in photobacterium broth (chemical composition listed in reference [44]) on agar slants in test tubes. Their log growth was empirically determined to be $48-72 \mathrm{~h}$ after the initial inoculation. Photo-bacterium marine broth $(10-20 \mathrm{~mL})$ was added to each inoculated agar tube without agitation to make suspensions of the micro-organism. The micro-organisms were held in complete darkness until the time of their exposure (see below) which was done under a dimmed visible (fluorescence) lighting. Suspensions of bacteria $(200 \mu \mathrm{L})$ were transferred to a 96 well, white culture plate (Costar Inc., Washington, DC, USA). Their luminescence signal of these untreated suspensions was first adjusted with additional broth to produce a uniform baseline emission of 800-1000 chemiluminescent units. Control readings were taken of wells containing: (broth $+/-$ organisms; broth $+/-\mathrm{nTiO}_{2}$ samples; broth + / - organisms $+/-\mathrm{nTiO}_{2}$ samples). None of control treatments generated significant signal and were discounted in the calculations. For the viability testing, aliquots of the individual groups of as-syn-nTiO $2(500-2000 \mu \mathrm{g} / \mathrm{mL})$ were administered to wells containing population-corrected Vibrio fischeri at 10-fold concentrations ( $n=6$ well/concentration). Readings were taken $<30 \mathrm{~s}$ after exposure and used as the $(t=0)$ baseline value. Reduction of luminescence was recorded at three post-exposure time intervals ( $t=15,30$, and $60 \mathrm{~min}$ ) using a LMAX $\mathrm{II}^{384}$ luminescent plate reader (Molecular Device, Sunnyvale, CA, USA) and the results were used to measure loss of viability. Each assay was replicated 4-6 times and representative data presented. Data were collected using Softpro5 (SoftPro, Raleigh, NC, USA) and transferred to Excel software where they were normalized to their individual baseline $(t=0)$. Linear correlation $R^{2}$ values were calculated and plotted against individual physicochemical characteristics using Excel software.

\subsection{Transmission and Scanning Electron Microscopy}

For transmission electron microscopy (TEM) examination of $\mathrm{nTiO}_{2}$, samples were sonicated (2510R-DH, Branson Ultrasonics, Danbury, CT, USA) in HPLC grade methanol (Pharmco, Brookfield, CT, USA) for $5 \mathrm{~min}$, transferred to a carbon coated 200 mesh, copper grid (EMS), and photographed using a JEM-2010F (JEOL) high resolution TEM (HR-TEM) with field emission of $200 \mathrm{kV}$. The diameter of particles was measured using ImageJ software (National Institute of Health, New York, NY, USA). For biological samples, the bacteria were exposed in Eppendorf $5 \mathrm{~mL}$ tubes for $1 \mathrm{~h}$, pelleted in marine broth, and washed several times in warm marine broth to remove all non-internalized particles. The pellets were fixed overnight in cold cacodylate-buffered $4 \%$ glutaraldehyde (Poly Scientific, Bayside, NY, USA) and processed using standard procedures. For scanning electron microscopy (SEM), samples were exposed to the individual as-syn-nTiO ${ }_{2}$ samples, pelleted and fixed for $2 \mathrm{~h}$ in cold cacodylate-buffered $4 \%$ glutaraldehyde (Poly Scientific, Bayside, NY, USA). They were then transferred to a $0.4 \mu \mathrm{m}$ nuclear pore filter and sputter-coated with 50 Angstrom gold-palladium before the examination with a JEOL SEM (JSM-5900 LV). 


\section{Results}

\subsection{Physicochemical Properties}

Table 1 summarizes the characterization of $\mathrm{nTiO}_{2}$, as reported elsewhere [41]. The as-syn-nTiO -100 sample had the largest BET surface area of $482 \mathrm{~m}^{2} / \mathrm{g}$ and pore volume of $0.659 \mathrm{~cm}^{3} / \mathrm{g}$. Increasing the calcination temperatures decreased the BET surface area and pore volume as expected [45,46]. Increasing the calcination temperature increased the crystal size and shifted amorphous, non-photoactive $\mathrm{nTiO}_{2}$ to anatase phase and subsequently to rutile phase. The zeta potential values of as-syn- $n \mathrm{TiO} 2$ measured in $500 \mu \mathrm{g} / \mathrm{mL}$ marine broth suspensions were all negatively charged ( -24 to $-28 \mathrm{mV}$ ) at these experimental conditions. The measurement of aggregate sizes by DLS was prevented due to rapid precipitation of each $\mathrm{nTiO}_{2}$ suspension in the highly osmolar photobacterium, dehydrated marine broth.

Table 1. All materials were previously synthesized and characterized [41].

\begin{tabular}{|c|c|c|c|c|c|}
\hline $\mathrm{TiO}_{2}$ Sample & $\begin{array}{l}\text { BET Area } \\
\left(\mathrm{m}^{2} / \mathrm{g}\right)\end{array}$ & $\begin{array}{l}\text { Pore Volume } \\
\qquad\left(\mathrm{cm}^{3} / \mathrm{g}\right)\end{array}$ & $\begin{array}{l}\text { Zeta Potential } \\
(\mathrm{mV})\end{array}$ & $\begin{array}{l}\text { Crystal Size } \\
\quad(\mathrm{nm})^{a}\end{array}$ & Crystal Phase $^{b}$ \\
\hline As-syn-100 & 482 & 0.659 & -28.7 & 4.5 & Amp \\
\hline As-syn-250 & 326 & 0.512 & -27.8 & 5.2 & Amp \\
\hline As-syn-400 & 134 & 0.375 & -22.8 & 10.5 & $\mathrm{~A}$ \\
\hline As-syn-500 & 75.4 & 0.302 & -27.9 & 15.3 & A \\
\hline As-syn-600 & 45.4 & 0.243 & -25.5 & 26.7 & A \\
\hline As-syn-700 & 11.8 & 0.094 & -26.9 & 42.5 & $A: R=4: 6$ \\
\hline As-syn-800 & 3.45 & 0.046 & -28.3 & 50.0 & $\mathrm{R}$ \\
\hline As-syn-900 & 0.95 & 0.02 & -24.7 & 80.0 & $\mathrm{R}$ \\
\hline
\end{tabular}

Amp = amorphous, $\mathrm{A}=$ anatase phase, $\mathrm{R}=$ rutile; ${ }^{\mathrm{a}}$ Calculated as the apparent size along the anatase (101) using the Scherrer equation $(D=0.9 \lambda / B \cdot \cos \theta)$ where $D$ is the average crystalline size, $\lambda$ is the wavelength of $X$-ray radiation $(0.154 \mathrm{~nm}), B$ is the full width at half maxima (FWHM) of the main peak of each phase, and $\theta$ is the diffraction angle; ${ }^{b}$ Calculated as the ratio of anatase and rutile using $X(\%)=\left(1 /\left[1+1.26\left(\mathrm{I}_{\mathrm{R}} / \mathrm{I}_{\mathrm{A}}\right)\right]\right) \times 100\left(\mathrm{I}_{\mathrm{A}}\right.$ : Integrated intensity of anatase (101) and $I_{R}$ : Integrated intensity of rutile (110)).

\subsection{Transmission Electron Microscopy}

TEM was used to examine the effects of calcination temperatures on particle size and crystal phase as shown in Figure 1. The crystal size increased when as-syn-nTiO $\mathrm{T}_{2}$ was calcined at higher temperatures. ImageJ software determined the sizes of the particles, calcined at 250,500 and $700{ }^{\circ} \mathrm{C}$ to be $5.7 \pm 1.5 \mathrm{~nm}, 14.0 \pm 2.9 \mathrm{~nm}$ and $47.5 \pm 21.9 \mathrm{~nm}$, respectively.

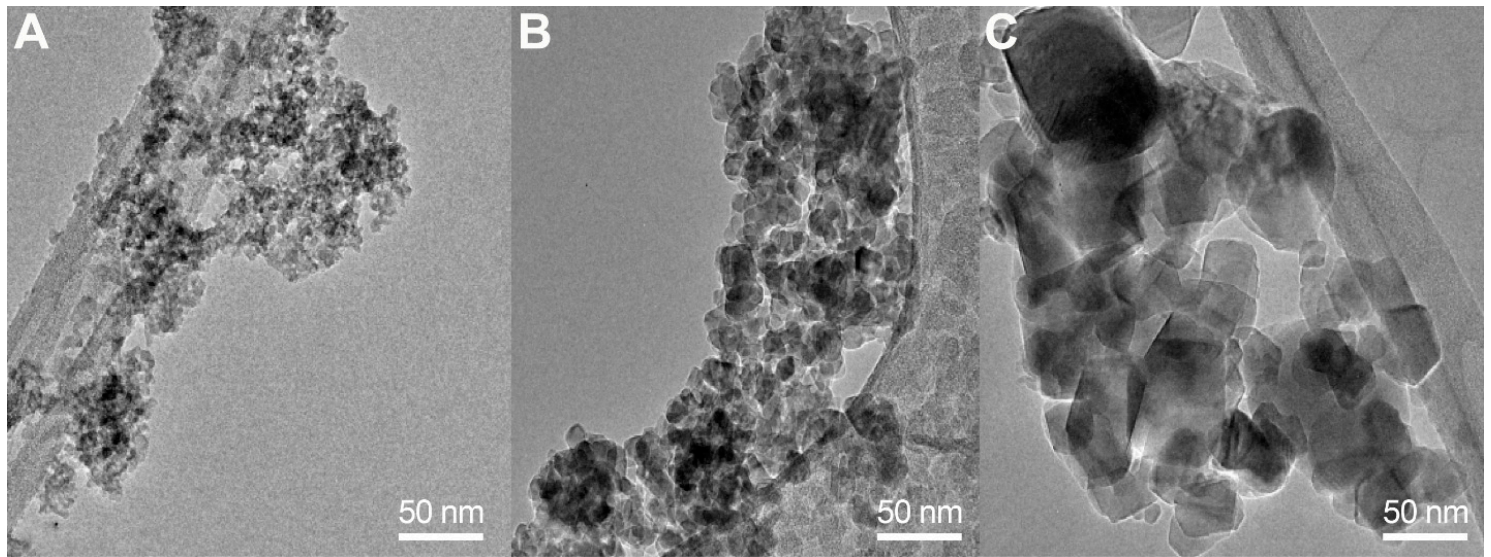

Figure 1. (A-C): TEM of the as-syn- $\mathrm{nTiO}_{2}$ particles indicated that increasing the calcination temperatures $\left(\mathbf{A}=250{ }^{\circ} \mathrm{C} ; \mathbf{B}=500{ }^{\circ} \mathrm{C} ; \mathbf{C}=700^{\circ} \mathrm{C}\right)$ increased particle size. Scale bars $=50 \mathrm{~nm}$. 
HR-TEM was also used to examine the effect of calcination temperature on crystal size and crystal phase of the samples as shown in Figure 2. The as-syn- $\mathrm{nTiO}_{2}-100$ sample (Figure 2A) exhibited an amorphous structure while the sample calcined at $500{ }^{\circ} \mathrm{C}$ (Figure $2 \mathrm{~B}$ ) showed crystals of $15-20 \mathrm{~nm}$ sizes and lattice spacing of $0.35 \mathrm{~nm}$ which corresponds to the (101) plane of anatase phase. As-syn-nTiO 2 calcined at $700{ }^{\circ} \mathrm{C}$ (Figure 2C) showed well-defined rutile crystals with sizes of 40-50 nm. The measured lattice spacing was $0.32 \mathrm{~nm}$, corresponding to the (110) plane of rutile phase.

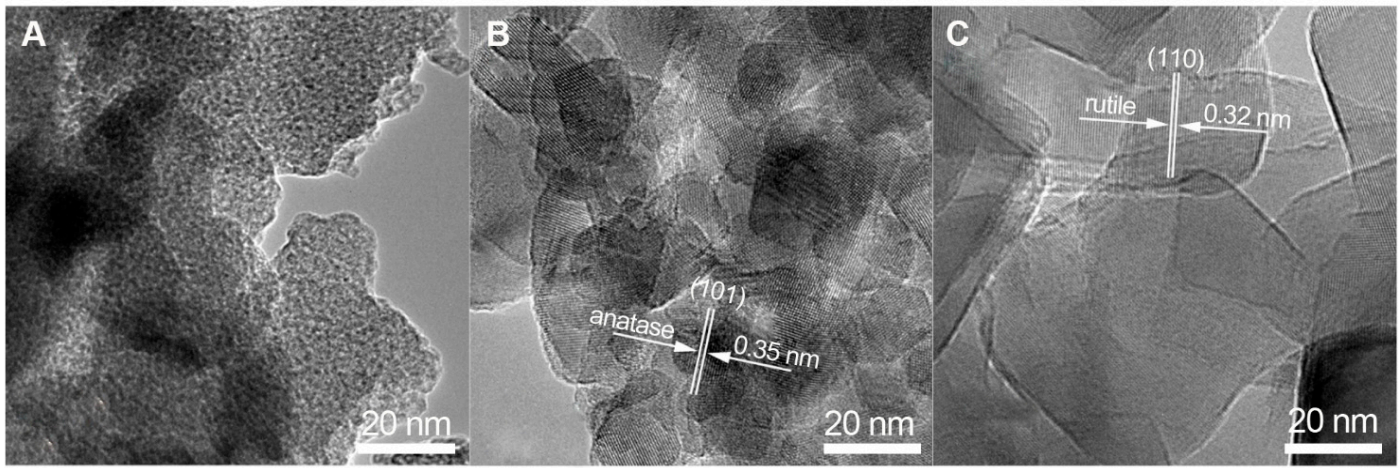

Figure 2. Non-calcined, as-syn- $\mathrm{TiO}_{2}$ dried at $100{ }^{\circ} \mathrm{C}(\mathbf{A})$, and materials calcined at $500{ }^{\circ} \mathrm{C}(\mathbf{B})$ and $700{ }^{\circ} \mathrm{C}(\mathrm{C})$ were photographed using HR-TEM. Scale bars $=20 \mathrm{~nm}$.

SEM was used to examine the control and treated microorganisms as presented in Figure 3. The control Vibrio fischeri (Figure 3A) appeared spherical and elongated with a thick outer membrane and an occasional single flagellum projecting from one pole. In contrast, $\mathrm{nTiO}_{2}$-treated organisms (Figure 3B) were more variable in appearance, with normal bacteria interspersed with rounded or overtly disrupted organisms. The seemingly normal organisms projected multiple filamentous extensions to each other and to the damaged Vibrio fischeri. Cell walls of the affected bacterium appeared damaged in spots which was followed by a breakdown of the cell membrane, cell rounding and the eventual leakage of their contents.

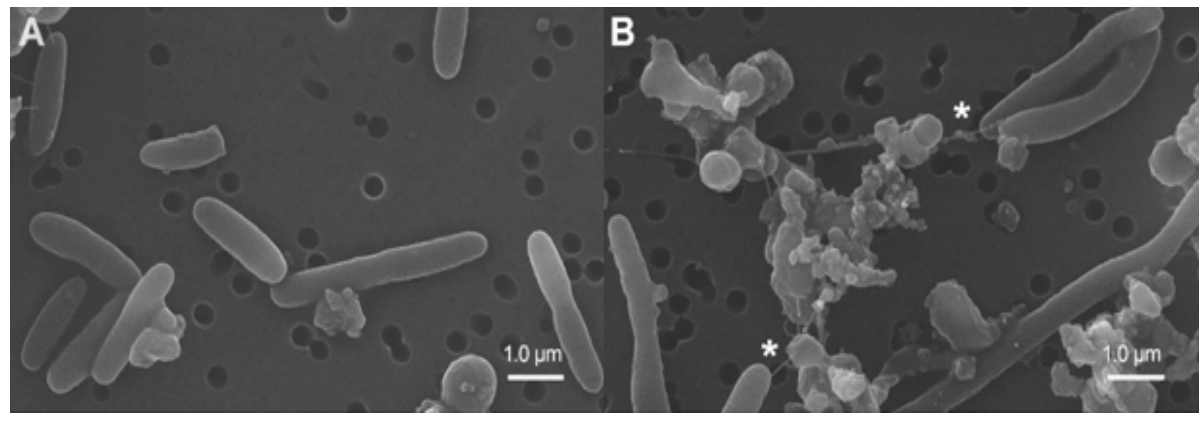

Figure 3. SEM images of control (A) and as-syn-nTiO 2 -treated (B) Vibrio fischeri. Multiple filamentous projections $\left(^{*}\right)$ are seen connecting seemingly unaffected bacteria and rounded, disrupted ones. Bacteria were exposed for $30 \mathrm{~min}$ to $500 \mu \mathrm{g} / \mathrm{mL}$ of $\mathrm{nTiO}_{2}$ calcined at $250{ }^{\circ} \mathrm{C}$.

\subsection{Viability Studies}

Reduction of luminescence was used as an index of viability and recorded in a dose-response fashion as early as 15 min post-exposure as shown in Figure 4. Data were normalized to their individual post-exposure values at $t=0$. Viability data indicated that the toxicity of the $\mathrm{nTiO}_{2}$ series corresponded to their calcination temperatures and a simple rank order indicated that high biocidal toxicity related inversely to higher calcination temperatures (i.e., small crystals demonstrate high biocidal toxicity) (data not shown). 
A.

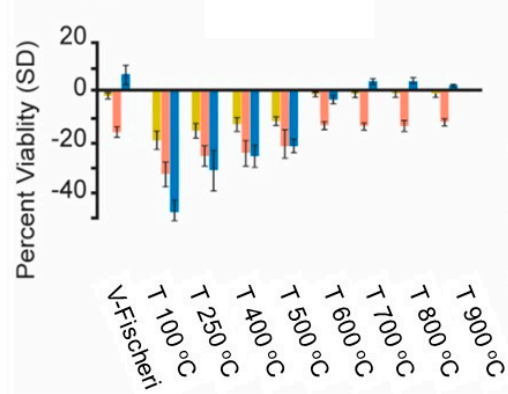

B.

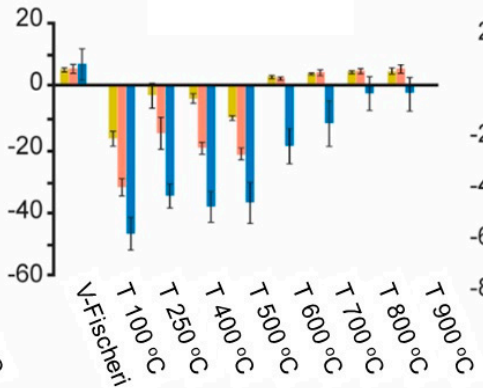

C.

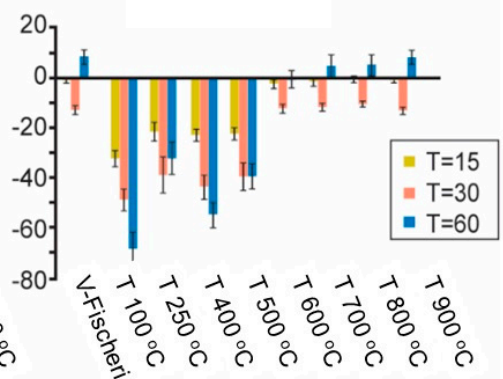

Figure 4. Reduction of luminescence was measured at $15-60 \mathrm{~min}$ in response to the series of as-syn-nTiO 2 at 500-2000 $\mu \mathrm{g} / \mathrm{mL}$ exposures. Higher toxicity corresponded to those $\mathrm{nTiO}_{2} \mathrm{materials}$ dried/calcined at the lower temperatures. (A) Toxicity of $\mathrm{nTiO}_{2}$ with $500 \mu \mathrm{g} / \mathrm{mL}$ exposure, (B) Toxicity of $\mathrm{nTiO}_{2}$ with $1000 \mu \mathrm{g} / \mathrm{mL}$ exposure, and (C) Toxicity of $\mathrm{nTiO}_{2}$ with $2000 \mu \mathrm{g} / \mathrm{mL}$ exposure.

\subsection{Linear Correlation}

$R^{2}$ values were calculated on the viability studies and plotted using Excel software. Similar ranking based on $R^{2}$ values were seen at all time-points and concentrations and indicated that high toxicity was associated with large BET surface area and pore volume, and small crystal size. The highest $\mathrm{R}^{2}$ values, correlating lethality with pore volume, BET surface area and crystal size appeared highest in the groups exposed to $500 \mu \mathrm{g} / \mathrm{mL}$ for $30 \mathrm{~min}$ and are graphically presented in Figure 5. These data indicated that high biocidal activity correlated with large BET surface area $\left(R^{2}=0.93\right.$, -slope $)$ and pore volume $\left(R^{2}=0.94,-\right.$ slope $)$, and small crystal size $\left(R^{2}=0.70,+\right.$ slope $)$. The values of $R^{2}$ for pore volume, BET surface area and crystal size after 30 min exposure to 1000 and $2000 \mu \mathrm{g} / \mathrm{mL}$ were calculated to be $(0.84,0.79,0.55$ and $0.66,0.64,0.49)$, respectively.

A.

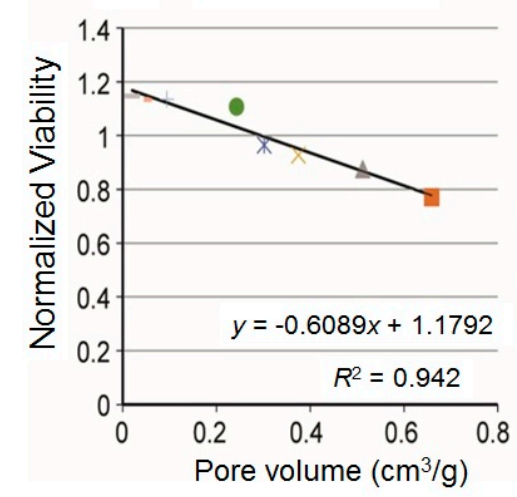

B.

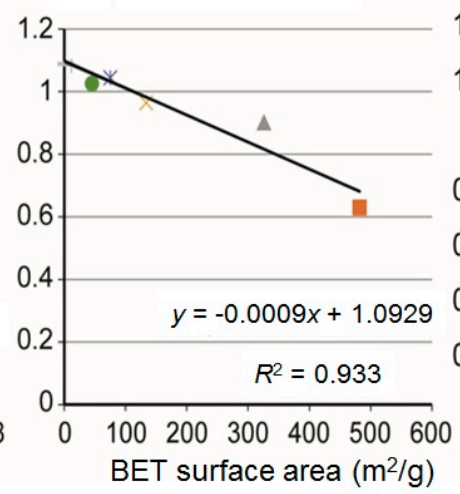

C.

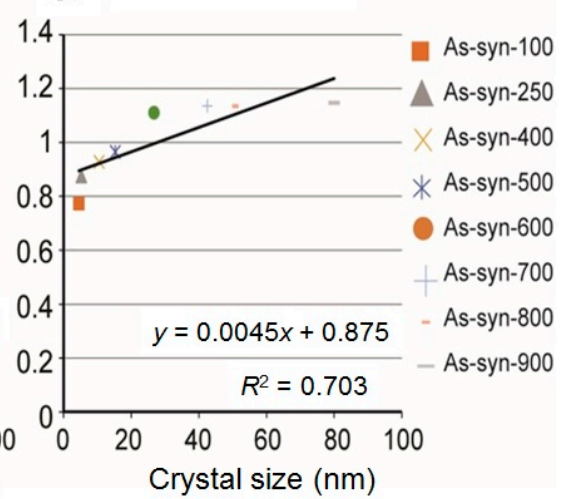

Figure 5. $R^{2}$ values, calculated from the $500 \mu \mathrm{g} / \mathrm{mL}, 30 \mathrm{~min}$ exposure, are shown. These values are representative of treatments at other times and exposure concentrations. The numbers next to "as-syn" sample represent its individual calcination temperature $\left({ }^{\circ} \mathrm{C}\right)$. (A) Viability for pore volumes, (B) Viability for BET surface areas, and (C) Viability for crystal sizes.

\section{Discussion}

The primary aim of these experiments was to test a set of closely related $\mathrm{nTiO}_{2}$ for their biocidal activity and relate this toxicity to their specific physicochemical properties. The marine bacterium Vibrio fischeri was chosen as the target micro-organism since $\mathrm{nTiO}_{2}$ affects a range of organisms in marine ecosystems [9,47-52]. 


\subsection{Physicochemical Effects of Calcination Temperatures}

The different calcination temperatures $\left(250-900{ }^{\circ} \mathrm{C}\right)$ used in the synthesis produced a series of modified materials with subtle differences in their physicochemical properties. An overview of these properties (Table 1) indicated that low calcination temperatures related to large BET surface area, large pore volume and small crystal size. HR-TEM showed that increasing the calcination temperature from 500 to $700{ }^{\circ} \mathrm{C}$ shifted the crystal phase of $\mathrm{nTiO}_{2}$ from anatase towards rutile. Data from related studies [53-55] also showed that altering the calcination temperature changed the crystallographic properties of as-syn- $\mathrm{nTiO}_{2}$. Increasing the calcination temperatures also increased the crystal size due to sintering and growth of particles. The crystal sizes measured from the HR-TEM micrographs using ImageJ software and those given in Table 1 which were calculated from XRD data [41], differed slightly. However, both calculations indicated that larger $\mathrm{nTiO}_{2}$ crystals were formed at higher calcination temperatures.

\subsection{Biocidal Effects}

The SEM micrograph shown in Figure 3B was representative of the exposed Vibrio fischeri. It suggests membrane damage and rounding of the micro-organism as its membranous network broke-down. Other studies have used TEM and biochemical analysis to describe similar effects of UV and visible light activated $\mathrm{TiO}_{2}$ and have documented a leakage of ions and decreases in membrane fluidity in Escherichia coli (E. coli) and Staphylococcus aureus [56,57]. The explanation for the differences in vulnerability of micro-organisms to $\mathrm{nTiO}_{2}$ is unclear but in part reflects the different thickness of the cell walls of gram $^{+} /$gram $^{-}$bacteria [58,59].

A number of research studies have reported on the toxicity of nanoTiO ${ }_{2}$ in various micro-organisms (e.g., E. coli, Staphylococcus aureus, Enterococcus faecalis, coliform) and fungi (Candida albicans, Aspergillus niger). These studies have primarily used UV- or visible ("doped") light-activated materials and a variety of endpoints and exposure time-points, making a comparison among studies difficult. In general, bulk and even nanoTiO $\mathrm{Tin}_{2}$ most forms, show low-toxicity to organisms and even in the case of UV-activated $\mathrm{TiO}_{2}$, concentrations of $800 \mu \mathrm{g} / \mathrm{mL}$ are required to kill $100 \%$ of the organism (coliform) in polluted waters [4]. This value might be compared with the biocidal effects (Figure 5A) associated with exposures to $500 \mu \mathrm{g} / \mathrm{mL}$ calcined $\mathrm{TiO}_{2}$ samples.

Several research studies have examined the effects of visible light-activated, nanostructured $\mathrm{TiO}_{2}$ (VLA nano- $\mathrm{TiO}_{2}$ ) on Vibrio fischeri, using surface coatings [60,61]; or different "doping" agents [62]. One study [63] examined the relative phenol degradation activity in a series of $\mathrm{nTiO}_{2}$ samples generated after calcination at $350-750{ }^{\circ} \mathrm{C}$. Similar to our findings, they found that the materials calcined at lower temperatures showed the highest phenol degradation activity and were most sensitive to visible light. Given this, the present study represents a unique contribution to the field as it examines the biocidal activity of nine molecularly related VLA nano- $\mathrm{TiO}_{2}$ materials.

\subsection{Physicochemical Properties Influence Toxicity}

The viability data demonstrated a linkage between the viability of Vibrio fischeri and those modified $\mathrm{nTiO}_{2}$ groups with large BET surface area and pore volume, small crystal size, and amorphous-anatase crystal phases. The physicochemical properties of particles, especially nanoparticles, are fundamental to their toxicity. Among the properties thought to influence a particle's biological activation include the size, shape or topography, surface area, crystal structure, surface charge, porosity and the tendency to aggregate [64-69]. Although many studies associate surface area and crystalline size of nTiO ${ }_{2}$ with its toxicity, others relate toxicity more to the crystal structure and particle shape/topography. Numerous studies have linked small particle size with higher $\mathrm{nTiO}_{2}$ toxicity in rodents, eco-species, cell culture, and microorganisms [13,18,64,70-75]. Relationships between particle toxicity, and the particle's size and BET surface area have been repeatedly demonstrated in inhalation toxicology studies $[70,75,76]$. It has also been reported that nanosize $\mathrm{nTiO}_{2}$ can damage human bronchial epithelial cells (BEAS-2B) 
in the absence of photoactivation [77]. On a cellular lever, an ultrafine particle size is thought to facilitate movement through cellular barriers and give the particle closer proximity to vulnerable subcellular systems (e.g., nucleic acids, enzymes) [65,78-80].

The crystal phase of $\mathrm{nTiO}_{2}$ also seems to influence toxicity with anatase being more toxic to a variety of species $[15,64,81,82]$ while other studies associate a higher toxicity and nucleic acid damage with a mixture of rutile/anatase phases $[77,83]$.

Aggregation is also considered to be a factor in $\mathrm{nTiO}_{2}$ toxicity since it affects particle shape, size and bioavailability $[20,74,76,84]$. Aggregation is affected by $\mathrm{pH}$, ionic strength, and ionic identity (inorganic and organic) of aqueous suspensions. The relatively low toxicity associated with rutile phase particles has been attributed to their tendency to form larger aggregates in physiological exposure vehicles [15]. However, data from our study and others [76] failed to support a role for particle aggregation in $\mathrm{nTiO}_{2}$ toxicity. In the current study, exposure of our particles in the highly osmolar marine broth resulted in an immediate agglomeration and sedimentation. Yet, the biocidal activity of these materials showed a high correlation with the particle's size and surface properties as measured on dry particles or in distilled water. One explanation for this could be that the $\mathrm{nTiO}_{2}$ particles, although aggregated, still showed a sufficiently high fractal surface for the formation of ROS and resulting toxicity. It is possible that studying the response to aggregated nanomaterials could be as relevant as that of highly dispersed material if the aggregates retain the characteristics of material (e.g., a large specific surface area, fractal surface, and nanosize dimensions) after agglomeration. In all likelihood the biological activity of nanoparticles relates to physicochemical parameters yet to be rigorously tested in current toxicity screening studies such as redox activity, surface affinity or combinations of more conventional physicochemical properties.

A (primary) mechanism underlying the toxicity of both UV and VLA nTiO ${ }_{2}$ centers on ROS formation $[9,10]$. Studies have demonstrated a linear correlation between the amount of ROS generated by $\mathrm{TiO}_{2}$ and biocidal activity. The larger surface areas of those modified $\mathrm{TiO}_{2}$ calcined at lower temperatures might provide more absorption sites for UV and visible light and result in higher ROS formation. The larger surface area leads to high reactivity $[85,86]$. It is reasonable to assume that the higher surface area produced by the lower temperature modified $\mathrm{TiO}_{2}$ in our study would allow for a greater ROS generation and higher toxicity of these damaging free radicals. ROS formation is influenced by both the BET area and particle size $[9,23,51,87-90]$. Although this study did not directly address the formation of ROS, an association with ROS and the loss of viability of the Vibrio fischeri is suggested. At no time in the study were the bacteria nor the $\mathrm{nTiO}_{2}$ materials exposed to UV lighting. The modified particles were exposed to dim fluorescent lighting only during their sonication, as were the Vibrio fischeri during their dosing. We are confident that the biocidal activity recorded in these micro-organisms resulted from their exposure to $\mathrm{VLA} \mathrm{nTiO}_{2}$ and did not result from exposure to UV light. A number of studies have addressed this phenomenon and indicate that visible light is able to photo-activate $\mathrm{nTiO}_{2}$ and generate $\operatorname{ROS}[23,88,89,91]$.

\section{Conclusions}

Data generated in this study show an association between the physicochemical properties of $\mathrm{nTiO}_{2}$, calcined at a range of temperatures, and its biocidal activity to marine bacteria. Findings indicate that lower calcination temperatures produced larger BET surface areas and smaller crystal sizes which increased the toxicity of $\mathrm{nTiO}_{2}$ and suggests that calcination temperature should be considered an important parameter on the modification of $\mathrm{nTiO}_{2}$ biocidal toxicity. The commercially available, inexpensive, rapid "screen" assay used in this study can be useful to test groups of physicochemically related nanomaterials for their potential ecotoxicity risk. Altering a nanomaterials' toxicity with a relatively cost-effective technique promises to reduce its environmental burden and to develop a more sustainable nanomaterial for environmental remediation.

Acknowledgments: Acknowledgements are given to Valerie K. Lapham (Center for Electron Microscopy, North Carolina State University, Raleigh, NC, USA) for the preparation of SEM samples and to Molly Windsor 
(Systems Research and Applications (SRA) International graphics, Research Triangle Park, NC, USA) for the preparation of graphics and the Table of Contents illustration. In addition, Veronesi is now enjoying retirement after a 30 year career in (neuro) toxicology.

Author Contributions: Performing the experiment: Doris Betancourt and Bellina Veronesi; Synthesizing and Characterizing materials: Hyeok Choi, Miguel Pelaez, Changseok Han; Drafting manuscript: Changseok Han, Bellina Veronesi; Critical revision: Dionysios D. Dionysiou, Bellina Veronesi, Changseok Han; Planning and supervision of the research: Bellina Veronesi, Dionysiou D. Dionysiou.

Conflicts of Interest: The authors declare no conflict of interest.

Disclaimer: The contents of this manuscript do not necessarily reflect EPA policy. Mention of trade names or commercial products does not constitute endorsement or recommendation for use.

\section{References}

1. Jacobs, J.F.; van de Poel, I.; Osseweijer, P. Sunscreens with titanium dioxide $\left(\mathrm{TiO}_{2}\right)$ nano-particles: A societal experiment. Nanoethics 2010, 4, 103-113. [CrossRef] [PubMed]

2. Kongsong, P.; Sikong, L.; Niyomwas, S.; Rachpech, V. Photocatalytic antibacterial performance of glass fibers thin film coated with n-doped $\mathrm{SnO}_{2} / \mathrm{TiO}_{2}$. Sci. World J. 2014, 2014, 869706. [CrossRef] [PubMed]

3. Pelgrift, R.Y.; Friedman, A.J. Nanotechnology as a therapeutic tool to combat microbial resistance. Adv. Drug Deliv. Rev. 2013, 65, 1803-1815. [CrossRef] [PubMed]

4. Rahmani, A.; Samarghandi, M.; Samadi, M.; Nazemi, F. Photocatalytic disinfection of coliform bacteria using $\mathrm{UV} / \mathrm{TiO}_{2}$. J. Res. Health Sci. 2009, 9, 1-6. [PubMed]

5. Schilling, K.; Bradford, B.; Castelli, D.; Dufour, E.; Nash, J.F.; Pape, W.; Schulte, S.; Tooley, I.; van den Bosch, J.; Schellauf, F. Human safety review of "nano" titanium dioxide and zinc oxide. Photochem. Photobiol. Sci. 2010, 9, 495-509. [CrossRef] [PubMed]

6. Sethi, D.; Pal, A.; Sakthivel, R.; Pandey, S.; Dash, T.; Das, T.; Kumar, R. Water disinfection through photoactive modified Titania. J. Photochem. Photobiol. B Biol. 2014, 130, 310-317. [CrossRef] [PubMed]

7. Tsuang, Y.H.; Sun, J.S.; Huang, Y.C.; Lu, C.H.; Chang, W.H.S.; Wang, C.C. Studies of photokilling of bacteria using titanium dioxide nanoparticles. Artif. Organs 2008, 32, 167-174. [CrossRef] [PubMed]

8. Wang, S.Q.; Tooley, I.R. Photoprotection in the Era of Nanotechnology, Seminars in Cutaneous Medicine and Surgery; Frontline Medical Communications: Parsippany, NJ, USA, 2011; pp. 210-213.

9. Li, F.; Liang, Z.; Zheng, X.; Zhao, W.; Wu, M.; Wang, Z. Toxicity of nano- $\mathrm{TiO}_{2}$ on algae and the site of reactive oxygen species production. Aquat. Toxicol. 2015, 158, 1-13. [CrossRef] [PubMed]

10. Li, Y.; Zhang, W.; Niu, J.; Chen, Y. Mechanism of photogenerated reactive oxygen species and correlation with the antibacterial properties of engineered metal-oxide nanoparticles. ACS Nano 2012, 6, 5164-5173. [CrossRef] [PubMed]

11. Allahverdiyev, A.M.; Abamor, E.S.; Bagirova, M.; Rafailovich, M. Antimicrobial effects of $\mathrm{TiO}_{2}$ and $\mathrm{Ag}_{2} \mathrm{O}$ nanoparticles against drug-resistant bacteria and leishmania parasites. Future Microbiol. 2011, 6, 933-940. [CrossRef] [PubMed]

12. Maness, P.-C.; Smolinski, S.; Blake, D.M.; Huang, Z.; Wolfrum, E.J.; Jacoby, W.A. Bactericidal activity of photocatalytic $\mathrm{TiO}_{2}$ reaction: Toward an understanding of its killing mechanism. Appl. Environ. Microbiol. 1999, 65, 4094-4098. [PubMed]

13. Angelstorf, J.S.; Ahlf, W.; von der Kammer, F.; Heise, S. Impact of particle size and light exposure on the effects of $\mathrm{TiO}_{2}$ nanoparticles on caenorhabditis elegans. Environ. Toxicol. Chem. 2014, 33, 2288-2296. [CrossRef] [PubMed]

14. Blaise, C.; Gagné, F.; Férard, J.; Eullaffroy, P. Ecotoxicity of selected nano-materials to aquatic organisms. Environ. Toxicol. 2008, 23, 591-598. [CrossRef] [PubMed]

15. Clément, L.; Hurel, C.; Marmier, N. Toxicity of $\mathrm{TiO}_{2}$ nanoparticles to cladocerans, algae, rotifers and plants-effects of size and crystalline structure. Chemosphere 2013, 90, 1083-1090. [CrossRef] [PubMed]

16. Hall, S.; Bradley, T.; Moore, J.T.; Kuykindall, T.; Minella, L. Acute and chronic toxicity of nano-scale $\mathrm{TiO}_{2}$ particles to freshwater fish, cladocerans, and green algae, and effects of organic and inorganic substrate on $\mathrm{TiO}_{2}$ toxicity. Nanotoxicology 2009, 3, 91-97. [CrossRef]

17. Hu, C.; Li, M.; Cui, Y.; Li, D.; Chen, J.; Yang, L. Toxicological effects of $\mathrm{TiO}_{2}$ and $\mathrm{ZnO}$ nanoparticles in soil on earthworm Eisenia fetida. Soil Biol. Biochem. 2010, 42, 586-591. [CrossRef] 
18. Menard, A.; Drobne, D.; Jemec, A. Ecotoxicity of nanosized $\mathrm{TiO}_{2}$. Review of in vivo data. Environ. Pollut. 2011, 159, 677-684. [CrossRef] [PubMed]

19. Minetto, D.; Libralato, G.; Ghirardini, A.V. Ecotoxicity of engineered $\mathrm{TiO}_{2}$ nanoparticles to saltwater organisms: An overview. Environ. Int. 2014, 66, 18-27. [CrossRef] [PubMed]

20. Sharma, V.K. Aggregation and toxicity of titanium dioxide nanoparticles in aquatic environment-A review. J. Environ. Sci. Health Part A 2009, 44, 1485-1495. [CrossRef] [PubMed]

21. Sheng, L.; Wang, L.; Su, M.; Zhao, X.; Hu, R.; Yu, X.; Hong, J.; Liu, D.; Xu, B.; Zhu, Y. Mechanism of TiO 2 nanoparticle-induced neurotoxicity in zebrafish (Danio rerio). Environ. Toxicol. 2014, 31, 163-175. [CrossRef] [PubMed]

22. Tourinho, P.S.; Van Gestel, C.A.; Lofts, S.; Svendsen, C.; Soares, A.M.; Loureiro, S. Metal-based nanoparticles in soil: Fate, behavior, and effects on soil invertebrates. Environ. Toxicol. Chem. 2012, 31, 1679-1692. [CrossRef] [PubMed]

23. Banerjee, S.; Pillai, S.C.; Falaras, P.; O'shea, K.E.; Byrne, J.A.; Dionysiou, D.D. New insights into the mechanism of visible light photocatalysis. J. Phys. Chem. Lett. 2014, 5, 2543-2554. [CrossRef] [PubMed]

24. Chen, X.; Burda, C. Photoelectron spectroscopic investigation of nitrogen-doped Titania nanoparticles. J. Phys. Chem. B 2004, 108, 15446-15449. [CrossRef]

25. Liu, G.; Wang, X.; Chen, Z.; Cheng, H.-M.; Lu, G.Q.M. The role of crystal phase in determining photocatalytic activity of nitrogen doped $\mathrm{TiO}_{2}$. J. Colloid Interface Sci. 2009, 329, 331-338. [CrossRef] [PubMed]

26. Reddy, K.M.; Baruwati, B.; Jayalakshmi, M.; Rao, M.M.; Manorama, S.V. S-, N- and C-doped titanium dioxide nanoparticles: Synthesis, characterization and redox charge transfer study. J. Solid State Chem. 2005, 178, 3352-3358. [CrossRef]

27. Virkutyte, J.; Baruwati, B.; Varma, R.S. Visible light induced photobleaching of methylene blue over melamine-doped $\mathrm{TiO}_{2}$ nanocatalyst. Nanoscale 2010, 2, 1109-1111. [CrossRef] [PubMed]

28. Dunn, A.K. Vibrio fischeri metabolism: Symbiosis and beyond. Adv. Microb. Physiol. 2012, 61, 37. [PubMed]

29. Lopez-Roldan, R.; Kazlauskaite, L.; Ribo, J.; Riva, M.C.; González, S.; Cortina, J.L. Evaluation of an automated luminescent bacteria assay for in situ aquatic toxicity determination. Sci. Total Environ. 2012, 440, 307-313. [CrossRef] [PubMed]

30. Menz, J.; Schneider, M.; Kümmerer, K. Toxicity testing with luminescent bacteria-characterization of an automated method for the combined assessment of acute and chronic effects. Chemosphere 2013, 93, 990-996. [CrossRef] [PubMed]

31. Mortimer, M.; Kasemets, K.; Heinlaan, M.; Kurvet, I.; Kahru, A. High throughput kinetic Vibrio fischeri bioluminescence inhibition assay for study of toxic effects of nanoparticles. Toxicol. In Vitro 2008, 22, 1412-1417. [CrossRef] [PubMed]

32. Parvez, S.; Venkataraman, C.; Mukherji, S. A review on advantages of implementing luminescence inhibition test (Vibrio fischeri) for acute toxicity prediction of chemicals. Environ. Int. 2006, 32, 265-268. [CrossRef] [PubMed]

33. Pinto, P.C.; Costa, S.P.; Lima, J.L.; Saraiva, M.L.M. Automated high-throughput Vibrio fischeri assay for (eco) toxicity screening: Application to ionic liquids. Ecotoxicol. Environ. Saf. 2012, 80, 97-102. [CrossRef] [PubMed]

34. Stolper, P.; Fabel, S.; Weller, M.G.; Knopp, D.; Niessner, R. Whole-cell luminescence-based flow-through biodetector for toxicity testing. Anal. Bioanal. Chem. 2008, 390, 1181-1187. [CrossRef] [PubMed]

35. Heinlaan, M.; Kahru, A.; Kasemets, K.; Kurvet, I.; Waterlot, C.; Sepp, K.; Dubourguier, H.-C.; Douay, F. Rapid screening for soil ecotoxicity with a battery of luminescent bacteria tests. Altern. Lab. Anim.: ATLA 2007, 35, 101-110. [PubMed]

36. Paulovits, G.; Kováts, N.; Ács, A.; Ferincz, Á.; Kovacs, A.; Kakasi, B.; Nagy, S.; Kiss, G. Ecotoxicological characterisation of sedimentation in the kis-balaton water protection system. Acta Biol. Hung. 2012, 63, 268-276. [CrossRef] [PubMed]

37. Villa, S.; Migliorati, S.; Monti, G.S.; Vighi, M. Toxicity on the luminescent bacterium Vibrio fischeri (Beijerinck). II: Response to complex mixtures of heterogeneous chemicals at low levels of individual components. Ecotoxicol. Environ. Saf. 2012, 86, 93-100. [CrossRef] [PubMed]

38. Binaeian, E.; Attar, H.; Safekordi, A.A.; Saber, R.; Chaichi, M.J. Study on toxicity of seven manufactured nano particles and two phenolic compounds to bacteria Vibrio fischeri using homemade luminometer. Asian J. Chem. 2012, 24, 5211. 
39. Garcia, A.; Recillas, S.; Sánchez, A.; Font, X. The luminescent bacteria test to determine the acute toxicity of nanoparticle suspensions. Nanotoxic. Methods Protoc. 2012, 255-259.

40. Baun, A.; Hartmann, N.B.; Grieger, K.; Kusk, K.O. Ecotoxicity of engineered nanoparticles to aquatic invertebrates: A brief review and recommendations for future toxicity testing. Ecotoxicology 2008, 17, 387-395. [CrossRef] [PubMed]

41. Choi, H.; Kim, Y.J.; Varma, R.S.; Dionysiou, D.D. Thermally stable nanocrystalline $\mathrm{TiO}_{2}$ photocatalysts synthesized via sol-gel methods modified with ionic liquid and surfactant molecules. Chem. Mater. 2006, 18, 5377-5384. [CrossRef]

42. Diehl, A.; Levin, Y. Smoluchowski equation and the colloidal charge reversal. J. Chem. Phys. 2006, 125, 54902. [CrossRef] [PubMed]

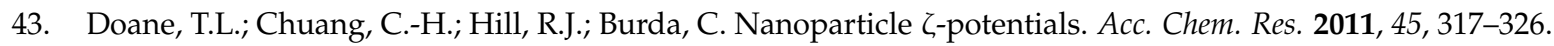
[CrossRef] [PubMed]

44. Safety Data Sheet. Available online: http://www.carolina.com/pdf/msds/photobrothdeghs.pdf (accessed on 19 December 2016).

45. Adam, F.; Appaturi, J.N.; Thankappan, R.; Nawi, M.A.M. Silica-tin nanotubes prepared from rice husk ash by sol-gel method: Characterization and its photocatalytic activity. Appl. Surf. Sci. 2010, 257, 811-816. [CrossRef]

46. Gaber, A.; Abdel-Rahim, M.; Abdel-Latief, A.; Abdel-Salam, M.N. Influence of calcination temperature on the structure and porosity of nanocrystalline $\mathrm{SnO}_{2}$ synthesized by a conventional precipitation method. Int. J. Electrochem. Sci. 2014, 9, 81-95.

47. Barmo, C.; Ciacci, C.; Canonico, B.; Fabbri, R.; Cortese, K.; Balbi, T.; Marcomini, A.; Pojana, G.; Gallo, G.; Canesi, $\mathrm{L}$. In vivo effects of $\mathrm{N}^{-\mathrm{TiO}_{2}}$ on digestive gland and immune function of the marine bivalve Mytilus galloprovincialis. Aquat. Toxicol. 2013, 132, 9-18. [CrossRef] [PubMed]

48. Della Torre, C.; Buonocore, F.; Frenzilli, G.; Corsolini, S.; Brunelli, A.; Guidi, P.; Kocan, A.; Mariottini, M.; Mottola, F.; Nigro, M. Influence of titanium dioxide nanoparticles on 2, 3, 7, 8-tetrachlorodibenzo-p-dioxin bioconcentration and toxicity in the marine fish european sea bass (Dicentrarchus labrax). Environ. Pollut. 2015, 196, 185-193. [CrossRef] [PubMed]

49. Dineshram, R.; Subasri, R.; Somaraju, K.; Jayaraj, K.; Vedaprakash, L.; Ratnam, K.; Joshi, S.; Venkatesan, R. Biofouling studies on nanoparticle-based metal oxide coatings on glass coupons exposed to marine environment. Colloids Surf. B Biointerfaces 2009, 74, 75-83. [CrossRef] [PubMed]

50. Galloway, T.; Lewis, C.; Dolciotti, I.; Johnston, B.D.; Moger, J.; Regoli, F. Sublethal toxicity of nano-titanium dioxide and carbon nanotubes in a sediment dwelling marine polychaete. Environ. Pollut. 2010, 158, 1748-1755. [CrossRef] [PubMed]

51. Xia, B.; Chen, B.; Sun, X.; Qu, K.; Ma, F.; Du, M. Interaction of $\mathrm{TiO}_{2}$ nanoparticles with the marine microalga Nitzschia closterium: Growth inhibition, oxidative stress and internalization. Sci. Total Environ. 2015, 508, 525-533. [CrossRef] [PubMed]

52. Zhu, X.; Zhou, J.; Cai, Z. The toxicity and oxidative stress of $\mathrm{TiO}_{2}$ nanoparticles in marine abalone (Haliotis diversicolor supertexta). Mar. Pollut. Bull. 2011, 63, 334-338. [CrossRef] [PubMed]

53. Chen, T.; Yan, J.; Li, Y. Genotoxicity of titanium dioxide nanoparticles. J. Food Drug Anal. 2014, 22, 95-104. [CrossRef] [PubMed]

54. Han, C.; Pelaez, M.; Likodimos, V.; Kontos, A.G.; Falaras, P.; O'Shea, K.; Dionysiou, D.D. Innovative visible light-activated sulfur doped $\mathrm{TiO}_{2}$ films for water treatment. Appl. Catal. B Environ. 2011, 107, 77-87. [CrossRef]

55. Puddu, V.; Choi, H.; Dionysiou, D.D.; Puma, G.L. $\mathrm{TiO}_{2}$ photocatalyst for indoor air remediation: Influence of crystallinity, crystal phase, and UV radiation intensity on trichloroethylene degradation. Appl. Catal. B Environ. 2010, 94, 211-218. [CrossRef]

56. Liou, J.-W.; Chang, H.-H. Bactericidal effects and mechanisms of visible light-responsive titanium dioxide photocatalysts on pathogenic bacteria. Arch. Immunol. Ther. Exp. 2012, 60, 267-275. [CrossRef] [PubMed]

57. Liu, P.; Duan, W.; Wang, Q.; Li, X. The damage of outer membrane of Escherichia coli in the presence of $\mathrm{TiO}_{2}$ combined with UV light. Colloids Surf. B Biointerfaces 2010, 78, 171-176. [CrossRef] [PubMed]

58. Swetha, S.; Kumari Singh, M.; Minchitha, K.; Geetha Balakrishna, R. Elucidation of cell killing mechanism by comparative analysis of photoreactions on different types of bacteria. Photochem. Photobiol. 2012, 88, 414-422. [CrossRef] [PubMed] 
59. Zhang, B.; Cui, D.; Liu, M.; Gong, H.; Huang, Y.; Han, F. Corn porous starch: Preparation, characterization and adsorption property. Int. J. Biol. Macromol. 2012, 50, 250-256. [CrossRef] [PubMed]

60. Sadowski, R.; Strus, M.; Buchalska, M.; Heczko, P.B.; Macyk, W. Visible light induced photocatalytic inactivation of bacteria by modified titanium dioxide films on organic polymers. Photochem. Photobiol. Sci. 2015, 14, 514-519. [CrossRef] [PubMed]

61. Tallósy, S.P.; Janovák, L.; Ménesi, J.; Nagy, E.; Juhász, Á.; Balázs, L.; Deme, I.; Buzás, N.; Dékány, I. Investigation of the antibacterial effects of silver-modified $\mathrm{TiO}_{2}$ and $\mathrm{ZnO}$ plasmonic photocatalysts embedded in polymer thin films. Environ. Sci. Pollut. Res. 2014, 21, 11155-11167. [CrossRef] [PubMed]

62. Wong, M.-S.; Chu, W.-C.; Sun, D.-S.; Huang, H.-S.; Chen, J.-H.; Tsai, P.-J.; Lin, N.-T.; Yu, M.-S.; Hsu, S.-F.; Wang, S.-L. Visible-light-induced bactericidal activity of a nitrogen-doped titanium photocatalyst against human pathogens. Appl. Environ. Microbiol. 2006, 72, 6111-6116. [CrossRef] [PubMed]

63. Górska, P.; Zaleska, A.; Kowalska, E.; Klimczuk, T.; Sobczak, J.W.; Skwarek, E.; Janusz, W.; Hupka, J. $\mathrm{TiO}_{2}$ photoactivity in vis and UV light: The influence of calcination temperature and surface properties. Appl. Catal. B Environ. 2008, 84, 440-447. [CrossRef]

64. Johnston, H.J.; Hutchison, G.R.; Christensen, F.M.; Peters, S.; Hankin, S.; Stone, V. Identification of the mechanisms that drive the toxicity of $\mathrm{TiO}_{2}$ particulates: The contribution of physicochemical characteristics. Part. Fibre Toxicol. 2009, 6, 33. [CrossRef] [PubMed]

65. Kreyling, W.G.; Semmler-Behnke, M.; Seitz, J.; Scymczak, W.; Wenk, A.; Mayer, P.; Takenaka, S.; Oberdörster, G. Size dependence of the translocation of inhaled iridium and carbon nanoparticle aggregates from the lung of rats to the blood and secondary target organs. Inhal. Toxicol. 2009, 21, 55-60. [CrossRef] [PubMed]

66. Oberdörster, G.; Maynard, A.; Donaldson, K.; Castranova, V.; Fitzpatrick, J.; Ausman, K.; Carter, J.; Karn, B.; Kreyling, W.; Lai, D. Principles for characterizing the potential human health effects from exposure to nanomaterials: Elements of a screening strategy. Part. Fibre Toxicol. 2005, 2, 8. [CrossRef] [PubMed]

67. Pal, S.; Tak, Y.K.; Song, J.M. Does the antibacterial activity of silver nanoparticles depend on the shape of the nanoparticle? A study of the gram-negative bacterium Escherichia coli. Appl. Environ. Microbiol. 2007, 73, 1712-1720. [CrossRef] [PubMed]

68. Rabolli, V.; Thomassen, L.C.; Princen, C.; Napierska, D.; Gonzalez, L.; Kirsch-Volders, M.; Hoet, P.H.; Huaux, F.; Kirschhock, C.E.; Martens, J.A. Influence of size, surface area and microporosity on the in vitro cytotoxic activity of amorphous silica nanoparticles in different cell types. Nanotoxicology 2010, 4, 307-318. [CrossRef] [PubMed]

69. Wiesenthal, A.; Hunter, L.; Wang, S.; Wickliffe, J.; Wilkerson, M. Nanoparticles: Small and mighty. Int. J. Dermatol. 2011, 50, 247-254. [CrossRef] [PubMed]

70. Grassian, V.H.; O'Shaughnessy, P.T.; Adamcakova-Dodd, A.; Pettibone, J.M.; Thorne, P.S. Inhalation exposure study of titanium dioxide nanoparticles with a primary particle size of 2 to $5 \mathrm{~nm}$. Environ. Health Perspect. 2007, 397-402. [CrossRef] [PubMed]

71. Hamzeh, M.; Sunahara, G.I. In vitro cytotoxicity and genotoxicity studies of titanium dioxide $\left(\mathrm{TiO}_{2}\right)$ nanoparticles in Chinese hamster lung fibroblast cells. Toxicol. In Vitro 2013, 27, 864-873. [CrossRef] [PubMed]

72. Iavicoli, I.; Leso, V.; Fontana, L.; Bergamaschi, A. Toxicological effects of titanium dioxide nanoparticles: A review of in vitro mammalian studies. Eur. Rev. Med. Pharmacol. Sci. 2011, 15, 481-508. [PubMed]

73. Musee, N.; Thwala, M.; Nota, N. The antibacterial effects of engineered nanomaterials: Implications for wastewater treatment plants. J. Environ. Monit. 2011, 13, 1164-1183. [CrossRef] [PubMed]

74. Noël, A.; Charbonneau, M.; Cloutier, Y.; Tardif, R.; Truchon, G. Rat pulmonary responses to inhaled nano- $\mathrm{TiO}_{2}$ : Effect of primary particle size and agglomeration state. Part. Fibre Toxicol. 2013, 10, 48. [CrossRef] [PubMed]

75. Oberdorster, G. Significance of particle parameters in the evaluation of exposure-dose-response relationships of inhaled particles. Inhal. Toxicol. 1995, 8, 73-89. [CrossRef]

76. Rabolli, V.; Thomassen, L.C.; Uwambayinema, F.; Martens, J.A.; Lison, D. The cytotoxic activity of amorphous silica nanoparticles is mainly influenced by surface area and not by aggregation. Toxicol. Lett. 2011, 206, 197-203. [CrossRef] [PubMed] 
77. Gurr, J.-R.; Wang, A.S.; Chen, C.-H.; Jan, K.-Y. Ultrafine titanium dioxide particles in the absence of photoactivation can induce oxidative damage to human bronchial epithelial cells. Toxicology 2005, 213, 66-73. [CrossRef] [PubMed]

78. Kreyling, W.G.; Semmler, M.; Möller, W. Dosimetry and toxicology of ultrafine particles. J. Aerosol Med. 2004, 17, 140-152. [CrossRef] [PubMed]

79. Nel, A. Air pollution-related illness: Effects of particles. Science 2005, 308, 804-806. [CrossRef] [PubMed]

80. Oberdörster, G.; Finkelstein, J.; Johnston, C.; Gelein, R.; Cox, C.; Baggs, R.; Elder, A. Ultrafine particles as inducers of acute lung injury: Mechanisms and correlation with age and disease. Health Effects Inst. 2000, 96, 1-88.

81. Jin, C.; Tang, Y.; Yang, F.G.; Li, X.L.; Xu, S.; Fan, X.Y.; Huang, Y.Y.; Yang, Y.J. Cellular toxicity of TiO nanoparticles in anatase and rutile crystal phase. Biol. Trace Elem. Res. 2011, 141, 3-15. [CrossRef] [PubMed]

82. Silva, R.M.; TeeSy, C.; Franzi, L.; Weir, A.; Westerhoff, P.; Evans, J.E.; Pinkerton, K.E. Biological response to nano-scale titanium dioxide $\left(\mathrm{TiO}_{2}\right)$ : Role of particle dose, shape, and retention. J. Toxicol. Environ. Health Part A 2013, 76, 953-972. [CrossRef] [PubMed]

83. Gerloff, K.; Fenoglio, I.; Carella, E.; Kolling, J.; Albrecht, C.; Boots, A.W.; Förster, I.; Schins, R.P. Distinctive toxicity of $\mathrm{TiO}_{2}$ rutile/anatase mixed phase nanoparticles on Caco-2 cells. Chem. Res. Toxicol. 2012, 25, 646-655. [CrossRef] [PubMed]

84. Maurer-Jones, M.A.; Lin, Y.-S.; Haynes, C.L. Functional assessment of metal oxide nanoparticle toxicity in immune cells. ACS Nano 2010, 4, 3363-3373. [CrossRef] [PubMed]

85. Buzea, C.; Pacheco, I.I.; Robbie, K. Nanomaterials and nanoparticles: Sources and toxicity. Biointerphases 2007, 2, MR17-MR71. [CrossRef] [PubMed]

86. Roduner, E. Size matters: Why nanomaterials are different. Chem. Soc. Rev. 2006, 35, 583-592. [CrossRef] [PubMed]

87. Erdem, A.; Metzler, D.; Cha, D.K.; Huang, C. The short-term toxic effects of $\mathrm{TiO}_{2}$ nanoparticles toward bacteria through viability, cellular respiration, and lipid peroxidation. Environ. Sci. Pollut. Res. 2015, 22, 17917-17924. [CrossRef] [PubMed]

88. Fotiou, T.; Triantis, T.M.; Kaloudis, T.; O'Shea, K.E.; Dionysiou, D.D.; Hiskia, A. Assessment of the roles of reactive oxygen species in the UV and visible light photocatalytic degradation of cyanotoxins and water taste and odor compounds using $\mathrm{C}-\mathrm{TiO}_{2}$. Water Res. 2016, 90, 52-61. [CrossRef] [PubMed]

89. Han, C.; Likodimos, V.; Khan, J.A.; Nadagouda, M.N.; Andersen, J.; Falaras, P.; Rosales-Lombardi, P.; Dionysiou, D.D. UV-visible light-activated Ag-decorated, monodisperse $\mathrm{TiO}_{2}$ aggregates for treatment of the pharmaceutical oxytetracycline. Environ. Sci. Pollut. Res. 2014, 21, 11781-11793. [CrossRef] [PubMed]

90. Yin, J.-J.; Liu, J.; Ehrenshaft, M.; Roberts, J.E.; Fu, P.P.; Mason, R.P.; Zhao, B. Phototoxicity of nano titanium dioxides in $\mathrm{HaCaT}$ keratinocytes-generation of reactive oxygen species and cell damage. Toxicol. Appl. Pharmacol. 2012, 263, 81-88. [CrossRef] [PubMed]

91. Pathakoti, K.; Morrow, S.; Han, C.; Pelaez, M.; He, X.; Dionysiou, D.D.; Hwang, H.-M. Photoinactivation of Escherichia coli by sulfur-doped and nitrogen-fluorine-codoped $\mathrm{TiO}_{2}$ nanoparticles under solar simulated light and visible light irradiation. Environ. Sci. Technol. 2013, 47, 9988-9996. [CrossRef] [PubMed]

(C) 2016 by the authors; licensee MDPI, Basel, Switzerland. This article is an open access article distributed under the terms and conditions of the Creative Commons Attribution (CC-BY) license (http://creativecommons.org/licenses/by/4.0/). 